\title{
Les langues étrangères en Europe. Apprentissage et pratiques (1450-1700), red. Marc Zuili i Susan Baddeley we uspółpracy z Jean-François Chappuit, PUPS, Paris 2012, ss. 328
}

(c) $\underset{\mathrm{gY}}{\ominus}$ Do DOI: http://dx.doi.org/10.12775/KLIO.2013.028

R óżnorodność językowa Europy wczesnonowożytnej stanowi bardzo Rinteresujące zagadnienie badawcze. Wielokrotnie podejmowano już studia nad nauczaniem greki i łaciny od średniowiecza po oświecenie. Pozostałe języki znalazły się na marginesie badań prowadzonych przez historyków i historyków języka. Były jednak obecne, wykładane, studiowane, gdyż ich znajomość konieczna była dla zaistnienia na królewskich dworach, nieodzowne były w karierze dyplomatycznej, czy w interesach handlowych. Znajomość języków obcych stała się jednym z fundamentów wykształcenia szlachetnie urodzonych oraz ambitnego mieszczaństwa. Nie brakowało więc inspiracji dla doskonalenia konwersacji, a nawet twórczości literackiej w języku francuskim, włoskim czy hiszpańskim, płynących z dworów Półwyspu Apenińskiego, pałacu wersalskiego, angielskich rezydencji. Pamiętać należy również o znaczeniu niderlandzkich i hanzeatyckich ośrodków (zwłaszcza portowych), urozmaicających ten arystokratyczny obraz Europy. Kontakt z obcym, innym motywował dodatkowo do podejmowania nauki i pogłębiania znajomości języków. Sprzyjał temu zjawisku postęp techniczny, rozpowszechnienie się drukarstwa oraz ułatwienia cyrkulacji książek i prasy. Są to zagadnienia, które potrzebują badań interdyscyplinarnych - nie tylko historycznych, ale także z zakresu nauk politycznych i społecznych.

Dostrzec należy, że szeroko zakrojone studia nad problematyką funkcjonowania języków w Europie, wzajemnych inspiracji i motywacji, pozwolą na „odzyskanie” obszarów, które wydawały się już jałowe i prezentujące niewielki potencjał badawczy. Tym bardziej należy docenić wspólną inicjatywę podjętą przez: ośrodek badawczy Uniwersytetu w Wersalu (Laboratoire "États, Société et Religion” pod kierunkiem Chantal Grell), Centre de recherche du château de Versailles oraz interdyscyplinarną grupę badaczy nad Europą Centralną i Wschodnią przy Uniwersytecie Paris 7 Denis Diderot. 
Publikacja ukazała się w ramach serii Mythes, critique et histoire (t. 15, pod redakcją Ch. Grell). W interesującym nas tomie zebrano, poza kilkunastostronicowym wprowadzeniem, 15 artykułów opatrzonych przypisami. Konstrukcja pracy jest bardzo przejrzysta. Książkę podzielono na trzy równe części, obejmujące różne zagadnienia z zakresu pedagogiki i praktyki nauczania języków, ich rzeczywistej znajomości oraz podręczników do ich nauki istniejących w Europie XVI i XVII wieku. Materiały uzupełnione zostały przez indeks osób oraz bibliografię. Ta ostatnia zbiera podstawowe starodruki (XV-XVIII wiek) oraz literaturę dotyczącą poruszanej w pracy tematyki. Całość zamyka spis treści.

Wprowadzający w treść tomu tekst autorstwa Jeana-Françoisa Chappuita, Susan Baddeley i Marca Zuiliego z Université Versailles SaintQuentin-en-Yvelines wyraźnie zarysowuje profil badań prezentowanych w pracy. Ukazuje on bowiem wieloznaczność języka przez jego liczne funkcje, prowadząc czytelnika do erazmiańskiego porównania języka do puszki Pandory (s. 11). Dlatego redaktorzy podkreślili, że nie może zabraknąć w tomie rozważań nad językami, podręcznikami i ich autorami.

Pierwsza część, dotycząca pedagogów, wykładowców języków oraz ich metod nauczania, zawiera pięć artykułów o podobnej objętości. Tekst rozpoczynający ten fragment zbioru, autorstwa Catherine Duclos-Talbotier, poświęcony został wpływom greckim i łacińskim w nauczaniu kastylijskiego przez Elio Antonio de Nebrija, wielkiego humanistę przełomu XV i XVI wieku, autora pierwszej gramatyki tego języka. Jest to studium lingwistyczne, które z jednej strony pokazuje przemiany jakie zaszły w języku kastylijskim, z drugiej strony znaczenie władzy królewskiej w przemianach gramatyki (s. 24-25). Tematykę nauczania kastylijskiego, jednak we Francji w XVII wieku, podjął też Marc Zuili. Podobnie jak w poprzednim artykule widać wyraźnie, jak wydarzenia polityczne przeplatają się z losami pedagogów, uczących języka kastylijskiego nad Sekwaną. Zaowocowało to licznymi podręcznikami i pracami ułatwiającymi poznanie tego pochodzącego zza Pirenejów języka. Susan Baddeley poświęciła swój artykuł nauczaniu języka francuskiego w Anglii w drugiej połowie XVI wieku, wskazując na trzy najważniejsze postaci - nauczycieli, których działalność na tym polu była kluczowa: Pierre’a du Ploiche, Claude’a de Sainliens, Jacquesa Bellot. Autorka ukazała spór pomiędzy nauczycielami języka francuskiego o po- 
chodzeniu angielskim z tymi o korzeniach francuskich (s. 69). Twórczość wspomnianego powyżej Jacquesa Bellota, a także Shaekespeare’a stały się tematem artykułu Jeana-Françoisa Chappuita. Jest to interesujące zestawienie języków, jakimi posługiwali się obaj pisarze. Autor kolejnego artykułu, zamykającego pierwszą część tomu, Étienne Krotky skupił swoją uwagę na postaci Jana Amosa Komeńskiego, czeskiego pedagoga i reformatora. Trafnie zauważył on, że inna wizja nauczania języków, w tym łaciny (wraz ze stworzeniem właściwych podręczników i metod), prowadzi do nowej filozofii i nowego postrzegania świata ${ }^{17}$.

W drugiej części, poświęconej już nie teoriom i wizjom nauczania języków, za którymi stali konkretni pedagodzy, lecz praktycznej znajomości języków obcych, znalazło się również pięć tekstów. W tematykę wprowadzają nas rozważania Nicole Bingen nad znajomością i zastosowaniem języka włoskiego przez dyplomację francuską w pierwszej połowie XVI wieku. Istotnym walorem tego ponad trzydziestostronicowego artykułu jest solidne oparcie go na materiale archiwalnym. Na przykładzie świata polityki wyraźnie widać przenikanie się języków i kultur - włoskiej i francuskiej ${ }^{18}$. Również w drugiej części podjęto temat sytuacji językowej w Hiszpanii w XVI wieku. Jacqueline Ferreras w swoich studiach skupiła się na ewolucji lingwistycznej, poddając pod rozważania zarówno kastylijski, jak i inne języki, które zdawały się konieczne dla właściwego funkcjonowania w świecie polityki na Półwyspie Iberyjskim: łacinę, grekę, francuski, toskański, niemiecki. Całość wywodów uzupełniają dwa aneksy: pierwszy to bibliografia, która zbiera starodruki wydane w Antwerpii w XVI i XVII wieku, a dotyczące różnych języków. Drugi jest fragmentem edycji szesnastowiecznego tekstu Voyage de Turquie, wykorzystanego w rozważaniach autorki. Wielojęzyczność obszaru Hanzy to tematyka artykułu Marie-Louise Pelus-Kaplan. W swoich

${ }^{17}$ Można tu przypomnieć uwagę Adama Fijałkowskiego o metodzie Komeńskiego, „która znajduje obecnie zastosowanie nie tylko w szkole, ilustrowanych słownikach, lecz także filmach fabularnych i dokumentalnych, dziennikarstwie, debatach politycznych, ilustratorstwie, reklamie, sztuce autoprezentacji, public relations itp." - idem, Orbis pictus. Świat malowany Jana Amosa Komeńskiego, Warszawa 2008, s. 29.

${ }_{18}$ Stanowi to interesujące rozwinięcie obserwacji Jeana-Françoisa Dubosta w jego La France italienne XVIe-XVIIe siècle z 1997 roku. Szczegółowe uwagi o języku zob.: ibidem, s. 123-125. 
badaniach zwróciła ona uwagę na kosmopolityczny wymiar tej organizacji handlowej, gdzie istotne miejsce odgrywał język niemiecki. Interesującym źródłem do poznania tego zjawiska okazały się podręczniki do sztuki konwersacji, czasem w kilku językach. Dwa kolejne artykuły, Macieja Serwańskiego i Macieja Foryckiego, przybliżyły zagadnienie znajomości języka francuskiego w Polsce szlacheckiej XVI i XVII wieku. W pierwszym ze wspomnianych tekstów autor skupił się przede wszystkim na miejscu kultury francuskiej, w tym także języka Moliera, na dworze królów polskich w XVI i XVII wieku. Maciej Serwański odnotował również specyfikę sytuacji w Gdańsku, który od początków XVII wieku stał się miejscem odgrywającym uprzywilejowaną rolę w budowaniu relacji polsko-francuskich (s. 199). Natomiast artykuł Macieja Foryckiego, zamykający omawianą część publikacji, poświęcony został już warstwie szlacheckiej, a dokładnie jednej rodzinie - Leszczyńskich. Autor, dla uzyskania pełniejszego obrazu, rozszerzył ramy chronologiczne swoich rozważań o pierwszą połowę XVIII wieku. Przykład ten pokazuje jak znaczące ambicje wykazywał ten ród pochodzący z Leszna i jak istotna dla ich realizacji była otwartość na zachodnie nowinki, dbałość o właściwą edukację w każdym pokoleniu, zwłaszcza językową. Jak wskazują studia Macieja Foryckiego takie pojmowanie kształcenia przełożyło się na rozwój samego miasta Leszna.

$\mathrm{Na}$ trzecią część, skupiającą się na zagadnieniu podręczników, słowników i metod nauczania języków obcych, składa się także pięć tekstów. Zdominowała ją tematyka edukacji z zakresu języków Półwyspu Iberyjskiego. Jedynie otwierający ten fragment książki artykuł Anne-Laure Metzger-Rambach dotyczy innego obszaru językowego. Zaprezentowała ona spojrzenie na język francuski oczyma Aleksandra Barleya, podkreślając nowatorstwo proponowanych zmian. Podstawą rozważań było jego dzieło The Introductory to wryte and to pronounce Frenche z 1521 roku. Studia, przeplatane bardzo licznymi cytatami, doprowadziły autorkę do konstatacji, że nauka języka francuskiego wpisała się w formację intelektualną angielskiego dżentelmena już u progu renesansu. Mercedes Banegas Saorin przedstawiła w swoim artykule rozważania lingwistyczne, przeprowadzając studia komparatystyczne dzieł Gabriela Meuriera oraz Baltazara de Sotomayor. Ukazała tym samym hiszpańskie zmagania nad uporządkowaniem zasad gramatyki i wymowy. Również Brigitte Lépinette skupiła 
się na szesnastym stuleciu, badając przemiany w funkcjach dydaktycznych colloquia przy nauce języka francuskiego i hiszpańskiego, uznając tą metodę za skuteczną w edukacji lingwistycznej nie tylko dzieci. Tematyka słowników oraz podręczników do gramatyki, pochodzących z drukarni rodziny Lacavalería z XVII wieku poruszona została w artykule Manuela Bruña Cuevasa. Czytelnikowi przybliżony został rynek wydawniczy publikacji do nauki kastylijskiego, katalońskiego i francuskiego. Ostatnią część zbioru zamyka artykuł Marie-Hélène Maux-Piovano. Podjęła się ona bardzo trudnego zadania ukazania metod, jakimi w XVII wieku uczono sztuki właściwej wymowy języka hiszpańskiego Francuzów zainteresowanych znajomością tego języka także ze względów politycznych. Bazą źródłową tych studiów są podręczniki z XVI i XVII wieku, które, jak wynika z badań, okazały się często zawodne w uzyskaniu perfekcyjnej artykulacji, jednak prowadziły do zrealizowania mniej ambitnego celu - komunikowania się w języku hiszpańskim.

Recenzowana praca to niewątpliwie ważny krok w badaniach nad funkcjonowaniem języków obcych w Europie XVI-XVII wieku. Żałować należy jedynie, że wśród kilkunastu tekstów nie znalazły się rozważania nad językami mniej rozpowszechnionymi, jak portugalski, czeski czy węgierski ${ }^{19}$. Wyraźnie zabrakło studiów nad złożonym politycznie, kulturowo i językowo obszarem Niderlandów; pewne zdziwienie budzi też brak obszerniejszych odniesień do edukacji jezuickiej, częstokroć decydującej dla stosunku do języków obcych na danym obszarze i przedłużającej koncepcję humanistyczną ${ }^{20}$. Uwagę czytelnika przykuwa, z jednej strony, próba stwo-

19 Zagadnienie jest nawet obszerniejsze, ponieważ można w nie włączyć stosunek nowożytnych użytkowników najbardziej popularnych języków do ich form dialektalnych czy historycznych. Pouczający jest w tym względzie przykład dwujęzycznego wydania Kroniki Anglosaskiej z 1692 roku, gdzie do staroangielskiego tekstu wydawca (Edmund Gibson) dodał własne tłumaczenie - łacińskie. Zob. Chronicon Saxonicum seu Annales Rerum in Anglia praecipue gestarum, ed. Edmund Gibson, Oxonii 1692.

${ }^{20}$ Elementem ważnej analizy mogłyby być tak podstawowe teksty, jak czwarta część Konstytucji Towarzystwa Jezusowego, poświęcona edukacji i przewidująca ewentualność nauczania arabskiego czy hinduskiego, a także „innych języków, które mogłyby być pożyteczne" oczywiście z wyraźnym nastawieniem misyjnym (rozdział 12 - por.: Ratio studiorum czyli Ustawa szkolna Towarzystwa Jezusowego (1599), Pułtusk 2000, s. 24). Ratio 
rzenia interdyscyplinarnego ujęcia problematyki, z drugiej jednak, takie założenie zaprowadziło redaktorów tomu w ślepy zaułek, gdyż powstało wrażenie braku spójności tekstów w ramach poszczególnych dyscyplin, czy tematyki. Pewien niedosyt pozostawia fakt, że rozważania zostały ucięte na 1700 roku w sposób, zdaje się, sztuczny. Ukazanie znaczącego dorobku Wieku Świateł z pewnością zbudowałoby obraz kompletniejszy i ciekawszy. Redaktorzy nie ustrzegli się usterek w niefrancuskojęzycznych słowach. Odnotować należy również, że przy tak ciekawych rozważaniach o nauczaniu, praktyce i podręcznikach do nauki języków zabrakło choćby streszczeń artykułów w innym języku kongresowym niż francuski. Tych kilka krytycznych spostrzeżeń nie zmienia jednak pozytywnej oceny książki, która z pewnością zainteresuje nie tylko historyków czy językoznawców, ale także osoby zainteresowane dorobkiem umysłowym XVI i XVII wieku.

Agnieszka Jakuboszczak (Poznań)

atque institutio studiorum SJ przewidywała także naukę chaldejskiego czy syryjskiego, tu z kolei dla lepszego rozumienia tekstów patrystycznych (ibidem, s. 35). 